\title{
Contribution of Essential Oils to the Fight against Microbial Biofilms-A Review
}

\author{
Diana Camelia Nuță ${ }^{1, *}$, Carmen Limban ${ }^{1}$, Cornel Chiriță ${ }^{2}$, Mariana Carmen Chifiriuc ${ }^{3} \mathbb{D}$, Teodora Costea ${ }^{4} \mathbb{D}$, \\ Petre Ioniță ${ }^{5}$ (D) Ioana Nicolau ${ }^{5}$ and Irina Zarafu ${ }^{5}$ (D)
}

1 Department of Pharmaceutical Chemistry, Faculty of Pharmacy, "Carol Davila” University of Medicine and Pharmacy, TraianVuia no.6, 020956 Bucharest, Romania; carmen.limban@umfcd.ro

2 Department of Pharmacology and Clinical Pharmacy, Faculty of Pharmacy, "Carol Davila" University of Medicine and Pharmacy, TraianVuia no.6, 020956 Bucharest, Romania; cornel.chirita@umfcd.ro

3 Department of Microbiology, Faculty of Biology, Universtity of Bucharest, AleeaPortocalelor no.1-3, 060101 Bucharest, Romania; carmen_balotescu@yahoo.com

4 Department of Pharmacognosy, Phytochemistry, Phytotherapy, Faculty of Pharmacy, "Carol Davila" University of Medicine and Pharmacy, TraianVuia no.6, 020956 Bucharest, Romania; teodora.costea@umfcd.ro

5 Department of Organic Chemistry, Biochemistry and Catalysis, Faculty of Chemistry, University of Bucharest, Regina Elisabeta no.4-12, 030018 Bucharest, Romania; petre.ionita@chimie.unibuc.ro (P.I.); ioana.nicolau@chimie.unibuc.ro (I.N.); irina.zarafu@chimie.unibuc.ro (I.Z.)

* Correspondence: diana.nuta@umfcd.ro

Citation: Nuță, D.C.; Limban, C.; Chiriță, C.; Chifiriuc, M.C.; Costea, T.; Ioniță, P.; Nicolau, I.; Zarafu, I. Contribution of Essential Oils to the Fight against Microbial Biofilms-A Review. Processes 2021, 9, 537. https://doi.org/10.3390/pr9030537

Academic Editors: Elwira Sieniawska, Greige-Gerges Helene and Adriana Trifan

Received: 12 February 2021

Accepted: 15 March 2021

Published: 18 March 2021

Publisher's Note: MDPI stays neutral with regard to jurisdictional claims in published maps and institutional affiliations.

Copyright: (c) 2021 by the authors. Licensee MDPI, Basel, Switzerland. This article is an open access article distributed under the terms and conditions of the Creative Commons Attribution (CC BY) license (https:/ / creativecommons.org/licenses/by/ $4.0 /)$.

\begin{abstract}
The increasing clinical use of artificial medical devices raises the issue of microbial contamination, which is a risk factor for the occurrence of biofilm-associated infections. A huge amount of scientific data highlights the promising potential of essential oils (EOs) to be used for the development of novel antibiofilm strategies. We aimed to review the relevant literature indexed in PubMed and Embase and to identify the recent directions in the field of EOs, as a new modality to eradicate microbial biofilms. We paid special attention to studies that explain the mechanisms of the microbicidal and antibiofilm activity of EOs, as well as their synergism with other antimicrobials. The EOs are difficult to test for their antimicrobial activity due to lipophilicity and volatility, so we have presented recent methods that facilitate these tests. There are presented the applications of EOs in chronic wounds and biofilm-mediated infection treatment, in the food industry and as air disinfectants. This analysis concludes that EOs are a source of antimicrobial agents that should not be neglected and that will probably provide new anti-infective therapeutic agents.
\end{abstract}

Keywords: essential oils; bacterial biofilm; antimicrobial; medical devices

\section{Introduction}

In the past decade, essential oils (EOs) use for the prophylaxis and therapy of biofilmassociated infections (BAIs) have become very popular. The universally accepted definition of a biofilm refers to a sessile multicellular community of microbial cells with a modified transcriptome and phenotype (exhibiting increased resistance to both therapeutic doses of current antimicrobials and immune effectors) that adhere to a surface and, among them, being protected by an auto-secreted extracellular polymeric matrix [1,2]. It is considered that BAIs represent up to $85 \%$ of the total microbial infections, occurring after microbial colonization of either viable tissues or medical devices and having serious consequences [3], because they are persistent and hard or impossible to treat, even in immunocompetent individuals.

On the other hand, the food manufacturing industry is facing the formation of microbial biofilms that can affect industrial processes, and researchers are in constant search of new ways to eradicate this phenomenon. The protective mechanisms of microbial cells within biofilms are multifactorial and differ from those that occurred in planktonic cells and include matrix impermeability, modified transcription rate, selection of persister cells, 
accumulation of antibiotic inactivating enzymes, increased horizontal transfer rate of resistance genes, etc. [4]. Therefore, biofilm cells can become up to100-1000 times more resistant to antimicrobial substances than planktonic cells [5]. This high phenotypic resistance, also called tolerance, interferes not only with the BAI treatment but also with the efficacy of surface disinfection processes [6,7]. The discovery of natural products with antimicrobial activity represents a direction of current research trying to limit microbial diseases.

Therefore, the purpose of this paper was to review the recent literature on EOs antibiofilm activities.

\section{Methods}

For this purpose, the PubMed (National Library of Medicine, Washington, DC) and Embase (Elsevier) databases were searched for all relevant articles written in English, using the following keywords: "essential oils", and "biofilm", and then "dentistry", "chronic wound infections", "medical devices", "food industry". We also reviewed additional relevant articles identified from the referenced citations. We limited our investigation to English-language journals.

EOs (also called volatile or ethereal oils) are natural aromatic oily liquids with complex compositions obtained from different plant organs by various methods, including expression, fermentation, enfleurage and extraction. The most used technique is steam distillation [8]. From the 20-60 low molecular weight components, which can be found in the composition of EOs in different amounts, at least one, such as terpenes and terpenoids or other aromatic compounds, exhibit antimicrobial activity [9] (Figure 1).<smiles>CC(C)=CCCC(C)=CCO</smiles>

Geraniol<smiles>CC(C)C12CCC(C)(CC1)O2</smiles>

Eucalyptol<smiles>C=CC(C)(O)CCC=C(C)C</smiles>

Linalool<smiles>CC1=CCC(C(C)(C)O)CC1</smiles>

alpha-Terpineol<smiles>C=CC(C)(CCC=C(C)C)C(=O)OC</smiles>

Linalyl acetate<smiles>CC1=CCC(O)(C(C)C)CC1</smiles>

Terpinen-4-ol<smiles>C=CC(C)(O)CCC=C(C)CCC=C(C)C</smiles>

trans-Nerolidol<smiles>CC(C)=CCCC(C)=CCO</smiles>

Nerol<smiles>C/C=C/CC/C=C(\C)C(C)=O</smiles>

Citral<smiles>CC(C)=CCC/C(C)=C\CC/C(C)=C/CO</smiles>

Farnesol<smiles>O=C/C=C\c1ccccc1</smiles>

Cinnamaldehyde<smiles>Cc1ccc(C(C)C)cc1O</smiles><smiles>CCCCCCCCCC=O</smiles><smiles>C=CCc1ccc(O)c(OC)c1</smiles><smiles>Cc1ccc(C(C)C)c(O)c1</smiles>

Thymol<smiles>CC1=CC(=O)C(C(C)C)CC1</smiles>

Piperitone<smiles>CC1CCC(C(C)C)C(O)C1</smiles>

Eugenol

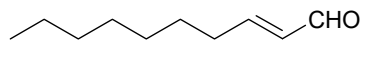

trans-2-Decenal

Figure 1. The main components of essential oils (EOs). 
EOs of vegetal origin have been used for millennia in ethnomedicine as a natural antimicrobial and antiviral agents. Their antimicrobial activity is due to the alteration of microbial cell envelope leading to cellular lysis with cell contents leakage and proton motive force inhibition. Their benefits result from the fact that microbial resistance is less probably to be installed, as compared to chemical substances, the facile preparation, high biocompatibility and biodegradability [6]. Besides their antimicrobial activity, EOs also exhibit anti-inflammatory effects. In addition, their antibiofilm activity came to researchers' attention in the last ten years [4].

\section{Discussion}

\subsection{EOs Mechanism of Action as Antibiofilm Agents}

The complex composition of EOs suggests that multiple mechanisms, probably acting synergically, are involved in their biological effects [3]. From the studied articles, we identified several types of mechanisms of action that we describe below.

In the review of Saviuc et al., it is shown that EOs are potent antibiofilm agents, acting by inhibition of the intercellular communication systems and by inducing changes in the substrate (referring to changing of redox potential, resistivity or $\mathrm{pH}$ ) [10]. EOs could also kill the biofilm embedded cells by the alteration of the cytoplasmic membrane due to their hydrophobic constituents [11]. The research performed by Selim and Burt groups revealed that the absence of the outer membrane in Gram-positive bacteria favors the direct interaction of the EOs with the cellular membrane, either affecting its permeability and causing the leakage of intracellular content or inactivating the bacterial enzymes [8,12].

As presented by Melo et al. in terms of action on the biofilm produced by S. aureus, the action of EOs depends on the hydrophobicity, reactivity and diffusion rate of EOs in the matrix, as well as to the composition and structure of the biofilm. The EOs can stop the formation of biofilm by blocking the quorum-sense system, inhibiting the transcription of flagellar genes or by interfering with bacterial motility [13].

Tang et al. analyzed the EOs from Amomum villosum Lour against methicillin-resistant S. aureus (MRSA) and established that the mechanism of action consists in reducing the bacterial adherence to inert surfaces. They realized the first proteomic study of the mechanism of action of $A$. villosum Lour EO against MRSA and showed that the inhibitory effect is dose-and temperature-dependent [14].

EOs could also increase the oxidative stress in microbial cells, causing damages of intracellular macromolecules, leading to cellular apoptosis., e.g., Das et al. found that Chamomile EO induced the accumulation of reactive oxygen species (superoxide and peroxide) that could be responsible forthe antimicrobial activity of this EO [15].

In their article from 2015, Fde et al. showed that geraniol, the main constituent of some EOs, such as Cymbopogon martini EO, inhibits the ergosterol synthesis, a major constituent of the fungal plasma membrane [16]. Cymbopogon citratus EO has an effect of inhibiting glucosyltransferase activity in addition to the mechanism of degrading membrane proteins and cell permeability. This enzyme is involved in glucans synthesis, which is important for the stabilization of E. coli O157: H7 biofilms. The study carried out by Ortega-Ramirez in 2020 presented a type of enzymatic mechanism that essential oils can have, which can overcome the resistance to disinfection processes of microorganisms that affect the food industry, such as E. coli O157: H7, which can form a very resistant biofilm [17].

\subsection{Disadvantages EOs Administration}

However, the EOs disadvantages should not be neglected, as Glinel et al. have shown. The chemical composition of EOs varies, depending on the ripeness, the harvesting season and the geographical origin. The EOs have low stability when exposed to temperature or UV radiation. Some EOs are toxic after internal administration or could cause hypersensitivity reactions, dizziness, headache, nausea, or lightheadedness, mostly after skin or mucosal administration [4]. 


\subsection{EOs Formulation}

Particular importance presents the research on obtaining different formulations and appropriate to the use of EOs, following at the same time an accurate determination of their mode of action.

In their article from 2019, Das et al. highlighted the disadvantages of EOs, due to their increased lipophilicity and volatility, which makes it difficult the evaluate the antimicrobial effect. That's why they proposed Pickering nanoemulsion of Chamomile EO as a new and promising formulation, which proved to be more effective and assuring the EO intracellular delivery when tested on a wide range of bacterial and yeast strains [15].

The Pickering oil-in-water (AEP) nanoemulsion of Artemisia annua EO, stabilized using silica nanoparticles, was very efficient against mature Candida biofilms, as compared to the emulsions stabilized with Tween- 80 and with the $A$. annua EO ethanolic solution, the possible mechanism of action being through the generation of the oxidative stress and superior penetration of lipid membranes, as demonstrated using the unilamellar liposomes model [18].For the same purpose, ethanol, methanol and dimethylsulfoxide (DMSO) solvents and Tween-80 or 20 surfactant-based formulations have been used to stabilize the hydrophobic EOs, reduce the volatility and improve the penetration of cellular envelope [19-22]. However, the need to obtain new formulations that increase the solubility of $\mathrm{EO}$ or the emulsification capacity in an aqueous medium for a more advanced release of the components still exists [22].

In the attempt to characterize the antimicrobial activity as precisely as possible, the aim was to incorporate the essential oils in modified cyclodextrins or silica nanoparticles [23-25].

Recently, inert and biocompatible solid particles have been used as stabilizing agents instead of surfactants to stabilize EO emulsions. This approach involves the adsorption of solid particles at the oil-water interface reducing the interfacial tension and thus, increasing the stability $[19,26]$.

\subsection{EOs as Antibiofilm Agents}

At present, there are only a few compounds with demonstrated activity agents have on fungal biofilms. For this reason, new anti-biofilm molecules are needed, and some essential oils have proven effective in combating antibacterial and antifungal biofilms. The chemical composition of commonly used EOs and the biofilm-producing microbial species used in antibiofilm tests are presented in Table 1. Table 2 shows the most tested EOs in terms of the antibiofilm effect on medical devices or different surfaces.

As it is presented in Table 2, much attention has been paid lately to Melaleuca alternifolia (tea tree oil) (TTO EO) [27], which exhibits antibacterial and antifungal activity, preventing the formation of biofilms on different surfaces having a high-risk of contamination.

A study from 2011 performed by Budzyñska et al. presents the activity of TTO EO, Lavandula angustifolia (lavender essential oil) (LEO), Melissa officinalis (Melissa essential oilor lemon balm) (MEO) and linalool, linalyl acetate, $\alpha$-terpineol, terpinen-4-ol on biofilms formed by S. aureus and E. coli reference strains. MEO, $\alpha$-terpineol and terpinen-4-ol, showed a higher antibiofilm effect than LEO and its major components, i.e., linalool and linalyl acetate. The tests demonstrated that $E$. coli biofilm was more susceptible than the $S$. aureus biofilms to the action of EOs, especially to TTO, that destroyed it after $1 \mathrm{~h}$ exposure to a $0.78 \%$ concentration, contrary to the opinion stating that Gram-negative microorganisms are more resistant to EOs. In comparison with LEO and TTO, the MEO effect is more dependent on the action time. The in vivo tests on biomedical surfaces of urinary catheters and tracheal tubes showed that TTO and terpinen-4-ol used at $2 \times$ MIC (minimal inhibitory concentration) caused visible biofilm eradication, while increased concentrations were required to eradicate the microbial biofilm on surgical mesh [5].

Karpanen and coworkers studied the antimicrobial effect of chlorhexidine digluconate, either alone or combined with TTO eucalyptus oil and thymol on planktonic and adherent S. epidermidis. Thymol exhibited a higher activity on biofilm cells. This was the first 
study in that EOs demonstrated the best potential of inhibiting the biofilm produced by S. epidermidis TK1 and RP62A when they were combined with chlorhexidine digluconate. This synergistic activity is particularly valuable for skin antisepsis and for removing $S$. epidermidis from hard disinfection surfaces [28].

The study was deepened by Kwiecinski et al., who also studied the antimicrobial action of TTO; this research demonstrated the TTO effectiveness against $S$. aureus clinical strains in different growth phases, including stationary phase and biofilms. The minimum biofilm eradication concentration was usually $2 \times \mathrm{CMI}$, lower than $1 \% v / v$. The inhibition of biofilm took place in $15 \mathrm{~min}$ at a TTO concentration >1\% v/v [29].

The TTO was also tested on clinical and reference C. albicans strains in biofilm growth state on both biotic (human epithelial cells) and abiotic (polystyrene) surfaces, but inhibition at $0.008 \%$ concentration occurred only for one C. albicans reference strain [30].

In another experiment, the Boswellia papyrifera resin EO (BEO) proved antibiofilm activity against $S$. epidermidis and S. aureus preformed biofilms of $24 \mathrm{~h}$, at concentrations close to the MICs. Sub-MIC concentrations of BEO exhibited a good inhibitory effect against $C$. albicans growth, adhesion, biofilm development, mature biofilm eradication (at $44 \mu \mathrm{g} / \mathrm{mL}$ concentration) and germ tube formation [31].

The sub-MIC concentrations of EO from T. vulgaris reduced the S. aureus biofilm development rate, inducing some cellular adaptation to this EO. This suggests that EOs treatments should envisage their rotation and combination with other biocides to prevent the emergence of resistant isolates [32].

A very recently published research on clove and thyme oils efficiency against Fusarium spp. development on soft contact lenses indicated that at concentrations lower than $50 \mu \mathrm{L} / \mathrm{L}$ that can be used without affecting the device material, the fungal cell adherence and formation were inhibited [33].

The Mentha piperita EO inhibits C. albicans and C. dubliniensis biofilm formation at a concentration of a maximum of $2 \mu \mathrm{L} / \mathrm{mL}$ in a dose-dependent manner. The effect is due to the increased concentration in menthol of this EO, which can be incorporated into the fungal cell membrane; the phenolic monoterpene, bearing a hydroxyl group on the phenolic ring, also exhibits antimicrobial effect due to the cytoplasmic membrane disruption. This mechanism of action results in the antifungal efficacy of EO of Mentha piperita on those strains resistant to azoles [34].

Table 1 indicates that much research has been devoted to identifying the EOs that can be used in biofilm eradication produced by S. aureus strains. In the study of Lee et al. (2014), from 83 EOs, nine of them (bay (Pimenta racemosa), cade (Juniperus oxycedrus), cedarwood (Calocedrus decurrens), frankincense (Boswellia carterii), lovage root (Levisticum officinale), oregano (Origanum vulgare), sandalwood (Santalum album), thyme red (Thymus vulgaris), and Vetiver Haiti (Cymbopogon martini) oils) inhibited the S. aureus biofilm at $0.01 \%(v / v)$ concentration. Three of them (black pepper (Piper nigrum), cananga (Cananga odorata), and myrrh (Commiphora myrrha) oils) at a sub-MIC exhibited a strong antibiofilm activity. One of the active compounds was cis-nerolidol $(0.01 \%(v / v))$, which proved to be more efficient than trans-nerolidol contained by the three EOs, inhibiting by more than $80 \%$ versus $45 \%$ the $S$. aureus biofilm growth. The black pepper EOs inhibited the expression of nuc1 and nuc2 (nucleases) and sarA (staphylococcal accessory regulator A), showing promise, together with cis-nerolidol for fighting MRSA and vancomycin-methicillin-resistant $S$. aureus infections [35].

The antimicrobial effect of carvacrol is often described in the literatureand the EOs rich in this compound, such as Satureja hortensis one (even in sub-MIC concentrations), proved to inhibit Candida, Staphylococcus and periodontal bacteria biofilms [36].

Gomes et al. demonstrated the efficiency of farnesol on S. epidermidis (one of the main nosocomial agents of indwelling medical devices BAIs) biofilm, producing significant destruction of biofilm structure and a significative reduction of biofilm thickness [37].

Gursoy et al. studied the antibiofilm activity of Satureja hortensis essential oil, tested on Candida and Staphylococcus biofilms, at and $0.03 \%$ and $0.06 \%$ concentrations. The growth 
inhibitory effect against periodontal bacteria and the anti-biofilm effect in subinhibitory concentration was registered [36].

The EOs from two plants from the Apiaceae family, Ferula asafetida and Dorema aucheri, were also tested for their antibiofilm activity against $P$. aeruginosa using $25 \mu \mathrm{g} / \mathrm{mL}$ concentration. Ferula EO decreased pigmentogenesis, protease and biofilm development, while Dorema EO affected only pyoverdine and elastase production [38].

The EOs of Cinnamomum burmannii and Massoia aromatic are another source of antibiofilm agents, proving to inhibit both P. aeruginosa and S. aureus biofilms. The effectiveness of these EOs can be due to their main components, highlighted by GC-MS analysis, which are cinnamic aldehyde and massoia lactone, respectively [39].

Kavanaugh and Ribbeck demonstrated that the EOs of cassia, Peru balsam, and red thyme oils are very efficient against MRSA biofilms. In addition, the three EOs at MIC values have also inhibited P. aeruginosa biofilm cells; for cassia EO $(0.2 \%)$, the effect is more intensive than that of colistin $\left(3 \mu \mathrm{g} \mathrm{mL} L^{-1}\right)$ [7].

The Eucalyptus smithii and Juniperus communis EOs inhibited both initial phases as well as the maturation of biofilms formed by S. aureus and P. aeruginosa respiratory isolates and reference strains [40].

A study of antibiofilm effect from 2014 used EOs from Lamiaceae and Apiaceae families (Ammi visnaga, Ammoides verticillata, Artemisia arborescens, Dittrichia graveolens, Lavandula dentate, Lavandula multifida, Mentha piperita, Origanum vulgare, Rosmarinus eriocalyx, Thymbra capitata), rich in oxygenated monoterpenes (mostly alcohols, such as thymol, carvacrol, linalool).The EOs from T. capitata and O. glandulosum (0.75-1.5\%) inhibited E. faecalis biofilms, similar to those extracted from A. verticillata and L. multifida (1.50-3.00\%). The study also confirmed that the administration of EOs is more efficient than the administration of the main component itself [41]. The Baccharis psiadioides (Asteraceae) EO, known for their antipyretic and anti-inflammatory properties, as well as a snake bites antidote, has been proved to exhibit antimicrobial and antibiofilm action on 13 E. faecalis resistant strains [42].

Many studies have focused on the research of eugenol, found as a major compound in clove (S. aromaticum) EO, and of citral, containing geranial (trans-citral, citral A) and neral (cis-citral, citral B), found in the citrus plants leaves and fruits. Eugenol acts by disrupting cellular membrane permeability, while citral affects both the cytoplasmic/outer membrane as well as the stress response mediated by the sigma factor RpoSin E. coli [43].

The Thymbra capitata EO inhibited the preformed biofilms of different Candida spp. at 2xMIC, excepting C. glabrata, probably due to the increased content in phenols (carvacrol) [44]. Starting from these observations on antifungal activity of EOs, Dalleau et al. (2008) have tried to deepen this study by testing ten terpenes, the main components of EOs (carvacrol, citral, eucalyptol, eugenol, farnesol, geraniol, linalool, menthol, $\gamma$-terpinene, and thymol), on different Candida strains (C. albicans, C. parapsilosis, C. glabrata). The best activity was recorded using carvacrol against $C$. albicans, $C$. glabrata and C.parapsilosis biofilms, the effect being biofilm age and concentration-independent. They also obtained good results for geraniol and thymol [45]. In another study [46], the antibiofilm effect of Citrus limon and Zingiber officinale EOs were investigated, and it has been shown that they can be used against biofilms of Klebsiella ornithinolytica, K. oxytoca and K. terrigena.

In an interesting article from 2019, Kerekeset al. described the antibiotic effect of Cinnamomum zeylanicum, Origanum majorana, and Thymus vulgaris EOs on dual-species biofilms.

Studying the effect on the biofilm produced by L. monocytogenes SZMC 21307 and E. coli SZMC 0582, they found that treatment with cinnamon EO at concentrations of $1 \mathrm{mg} / \mathrm{mL}$ eradicated the dual biofilm. In the case of marjoram EO, the biofilm elimination started from $0.5 \mathrm{mg} / \mathrm{mL}$ concentration, and in the case of thyme EO, the inhibitory effect was detected starting with $1 \mathrm{mg} / \mathrm{mL}$ concentrations. These values were surprisingly much lower than those recorded in the eradication of monoculture biofilms. All studied 
EOs decreased biofilm formation but at concentrations higher than those required for monospecific biofilms eradication.

These polymicrobial biofilms can be found in the food industry, and the recorded results suggest the possible use of EOs as food preservatives, but however, their use is limited by the strong odor and taste, requiring further study to mitigate these effects [47].

The promising results on the antibiofilm effect of EOs have outlined a new challenge for researchers to study whether the association of EOs with antibiotics is beneficial. In this regard, Rosato et al. published in 2020 a series of research that is intended to be just the beginning of a comprehensive study on the synergistic effect of EO antibiotics. They studied the activity of Cinnamomum zeylanicum, Mentha piperita, Origanum vulgare and Thymus vulgaris EOs associated with norfloxacin, oxacillin, and gentamicin on bacterial biofilm produced by S. aureus, S. epidermidis IG4, and E. faecalis. The synergistic effects were tested through the checkerboard microdilution method. The study showed that all EOs have a synergistic effect, the best being in combination with norfloxacin, leading, for example, in the case of Cinnamomum zeylanicum EO to a decrease from $128 \mu \mathrm{g} / \mathrm{mL}$ to $3.99 \mathrm{~g} / \mathrm{mL}$ of gentamicin MIC50.The advantages of combined therapy are obvious: the decrease of antibiotic doses and implicitly reducing the resistance to antimicrobial drugs [48].

\subsection{EOs Used in Dentistry}

Many studies were devoted to finding new irrigants or interappointment to remove the microbial biofilms formed in the mouth, which prevent endodontic treatments [49]. Therefore, there is a need for chemical substances as medications that have both antibacterial and antibiofilm activities. E. faecalis is commonly recovered from teeth with persistent endodontic infections, creating biofilms attached to the canal walls or located in isthmuses and ramifications from where are difficult to eliminate by current substances, such as sodium hypochlorite and chlorhexidine $[41,50]$. Microbial biofilms and smear layer must be eradicated during endodontic treatment. Because the substances used as chemical irrigants are not bio-friendly with the dental and peri-radicular tissues, different natural substances have been studied as disinfectantsof root canals [51]. Chloroformic solutions of eucalyptus and orange EOs associated with cetrimide at concentrations varying from $0.05 \%$ to $0.3 \%$ reduced the biofilm by $70-85 \%$. The two EOs enhanced the efficiency of cetrimide, which effectively eradicated the biofilms in lower doses, the synergic effect being probably due to lipophilic compounds (e.g., terpenoids or phenolics) [50].

The Melaleuca alternifolia EO used as a gel with antibacterial effect was very effective against oral $S$. mutans biofilm, decreasing the gingival bleeding index. Mouthwashes with this EO have also decreased not only $S$. mutans but also the total oral bacteria counts. The EO was used in 5\% concentration, which was well accepted, without side effects [52,53].

Testing several oral disinfectants, including those containing a mixture of Aloe vera and TTO, Smith et al. (2013) demonstrated that none of the mouthwashes effectively eradicated biofilms formed from oral and bloodstream isolates MRSA.The antibiofilm effect can be improved by increasing the concentration and exposure time [54]. Carvacrol and oregano oil were also the subjects of the research study undertaken by Nostro in 2007. Both of them are known for their effect on Staphylococcus strains; they showed in vitro effects on staphylococcal biofilms, the biofilm inhibitory concentrations values have registered at $2-4 x C M I$ values. Dental plaque biofilm plays an essential role in oral pathology, the etiology of dental caries, but also in contamination of dental materials surfaces, such as those used in the implant-prosthetic rehabilitation (implants, impression materials, alloys for prosthetic use, etc.) [55]. Due to the biofilm matrix destabilizing effect, thymol is used in the mouthwash with anti-plaque effects [56].

Cortelli et al. (2014) noted how important could be the use of EOs (menthol, thymol, and eucalyptol) for oral health by preventing the biofilm formation in patients with prostheses [57]. In several cases, the EOs can be more efficient than cetylpyridinium chloride [58]. Haas et al. suggested that EOs can be used daily, in the long-term, for reducing 
the supragingival plaque and, thus, gingivitis [59]. Quintas et al. have shown that EOs prevented de novo plaque-like biofilm development for $7 \mathrm{~h}$ after mouthwash, representing a possible alternative to chlorhexidine for the pre-surgical rinse or after periodontitis treatments [60,61]. In a study from 2013, Erriu et al. demonstrated that the mouthwash containing EOs compounds, such as eucalyptol, methyl salicylate, menthol and thymol, combined with ethanol, exhibits an improved antibiofilm activity at high dilution. The nonalcoholic mixture of EOs tested on Aggregatibacter actinomycetemcomitans strains had better anti-planktonic behavior [62]. It was also demonstrated the benefit of association of these EOs with xylitol in mouthrinse against $S$. mutans-derived biofilms, independent of the type of treatment or age of biofilm. This is a very promising treatment for the treatment and prevention of caries [63].The Mentha piperita and Rosmarinus officinalis EOs proved to be effective against $S$. mutans, one of the main agents of dental caries. Of the Mentha piperita EO, having a menthol concentration below 3.6\% was more effectivethan rosemary oil(containing piperitone as the main component) and chlorhexidine (at 4000 and $8000 \mathrm{ppm}$ ). The use of toothpaste blended with EOsindicated that lower concentrations of the EOs were more effective than chlorhexidine [64]. The association of chlorhexidine with EO is indicated for better antibiofilm activity in oral treatment [65].

Eugenol and citral could represent better alternatives to chlorhexidine because, at subinhibitory concentrations, they are affecting biofilm formation and virulence of methicillin-susceptible S. aureus, MRSA and L. monocytogenes strains, having a low-risk for selecting resistance [66].

Bersan et al. studied the EOs $(1 \mathrm{mg} / \mathrm{mL})$ from twenty medicinal and aromatic species on biofilms produced in vitro by different microbial strains and compared the results with nystatin and chlorhexidine digluconate. The Aloysia gratissima and Coriandrum spp. EOs have strongly inhibited C. albicans, Fusobacterium nucleatum, P. gingivalis, S. mitis and S. sanguis. The $C$. articulates EO inhibited F. nucleatum and P. gingivalis biofilms. A. gratissima $(1 \mathrm{mg} / \mathrm{mL}$ or $9 \%$ concentration) inhibited the $S$. mitis biofilm more intensively than chlorhexidine [67]. EOs, stannous fluoride and hexetidine associated with methylparaben and propylparaben decreased the in vitro peri-implant biofilm mass and activity by $39 \%$ to $56 \%$ and decreased gingivitis by $59 \%$ after continuous application. These EOs have also been shown to reduce the release of bacterial endotoxins and pathogenicity [68].

In a recent study, Marinković et al. studied the antibiofilm efficacy of Cymbopogon martini and Thymus zygis EOs on the multispecific biofilms of S. mitis, S. sanguinis and E. faecalis in the root canals of extracted teeth. They found that the addition of an oil-based irrigant to $1.5 \%$ sodium hypochlorite proved to be more efficient against biofilm development [69]. On the other side, exposure to biocides (e.g., triclosan) can increase the S. mutans hydrophobicity, increasing its susceptibility to EOs. Therefore, a combination of triclosancontaining toothpaste with EOS-based mouthrinse could reduce the acidic bacteria [70]. A good antibiofilm and anti-caries effect, comparable to that of chlorhexidine $(0.12 \%)$, was observed for a mouth rinse containing Matricaria chamomilla L. EO (PerioGard ${ }^{\circledR}-$ Palmolive). The antibiofilm effect has been evaluated as a decrease in Colony-forming units (CFUs) for total S. mutans, S. sobrinus and Lactobacillus sp., and the anti-caries effect has been studied as the effect on enamel demineralization compared to phosphate-buffered saline (PBS) solution. The authors found a mineral loss reduction by $39.4 \%$ in the case of mouthwash containing EO from Matricaria chamomilla L., very close to that of chlorhexidine (47.4\%). The authors considered that the experimental product having Chamomile EO significantly reduced enamel demineralization [71]. The Mentha spicata essential oil was tested for in vitro and in vivo antimicrobial and biofilm activities on S. mutans [72].

These results suggest that rosemary EO is efficient against cariogenic oral streptococci. Due to its major compound, eugenol, clove oil is a potent fungicidal, bactericidal and natural anesthetic compound. The Eucalyptus EO, reach in eucalyptol, showed antibiofilm activity against C. albicans biofilms [73]. The EOs from A. gratissima, Baccharis dracunculifolia, C. sativum, and Lippia sidoides demonstrated a potent inhibitory activity on S. mutans biofilm, probably due to the presence of thymol, carvacrol, and trans-nerolidol [74]. Mouthwashes 
containing Citrus hystrix leaf EO alone or in combination with chlorhexidine inhibited the periodontopathogenic bacteria and S. sanguinis and S. mutans biofilms [75]. The EO of $B$. dracunculifolia has been studied for use in dental care because it is known that this EO inhibits the growth of $S$. mutans. This EO reduced the rate of biofilm after one week of use, at the same level as triclosan, being a good candidate to be implemented in new material for dental care [76]. Curcuma longa EO (0.5 to $4 \mathrm{mg} / \mathrm{mL})$ inhibited the growth, acid production and $S$. mutans adherence to saliva-coated hydroxyapatite beads and biofilm development [77]. The EO extracted from seeds of the Butia capitata tree was tested on biofilms produced by aciduric bacteria, lactobacilli, and S. mutans, comparing with three commercial self-etching adhesives, and it was demonstrated that they were equally effective against tested microorganisms [78].

The Coriandrum sativum EOs exhibited an inhibitory activity against $C$. albicans oral isolates from patients with a periodontal disease, similar to nystatin, suggesting its promising potential for the prophylaxis and treatment of oral candidiasis [79]. The Citrus limonum and C. aurantium EOs exhibited an antibiofilm effect comparable to $0.2 \%$ chlorhexidine but lower than $1 \%$ sodium hypochlorite on multispecific biofilms formed by C. albicans, E. faecalis and E. coli [80]. C. sativum EO isprobably active through its major compounds (decanal and trans-2-decenal) that could bind membrane ergosterol, acting similarly to nystatin and amphotericin B. C. articulatus contains $\alpha$-pinene that could interfere with cellular envelopes integrity, respiratory chain and ion transport A. gratissima and L. sidoides EOs were bactericidal and inhibited the production extracellular polysaccharides in $S$. $m u-$ tans [81]. The C. sativum EO also inhibited the proteolytic activity of C. albicans and affected the normal morphology of yeast cells (at 156.0 to $312.50 \mathrm{mg} / \mathrm{mL}$ concentration), probably by affecting the membrane permeability, due to the presence of mono- and sesquiterpene hydrocarbons [82].

\subsection{EOs in Chronic Wound Infection Treatment}

Wounds chronicity is often associated with biofilm development. Farnesol and xylitol exhibited a significant inhibitory effect against $E$. faecalis biofilms, being, therefore, proposed as adjuvants for the treatment of chronic wound infections or caries [83]. Notably, Anghel et al. demonstrated the benefit of using a modified wound dressing nanofunctionalized with magnetite nanoparticles with sustained release of $S$. hortensis $\mathrm{EO}$ (rich in phenolic compounds, such as thymol, carvacrol, and para-cymene) against $C$. albicans biofilm [84].

\subsection{EOs in the BAIs Treatment}

BAIs are a major cause of morbidity and mortality in hospitalized patients. The treatment of biofilm-mediated infections requires the development of new antibiofilm strategies, which represent new scientific challenges.

When Park et al. (2007) tested the antibacterial effect of TTO on silicone tympanostomy tubes, they found that all tested concentration of EO $(100 \%, 50 \%, 10 \%$ in tween) produced a reduced bacterial adherence of all MRSA strains, which may be explained by the alteration of adherence factors present on the bacterial cell surface. The bacterial cultures were obtained from otorrhea in patients with chronic suppurative otitis media, and the antibiofilm effect of TTO was evaluated in comparison to vancomycin. The MRSA exhibited a similar susceptibility to $50 \%$ TTO and vancomycin. The authors proposed TTO as an alternative for pediatric MRSA otorrhea treatment with tympanostomy tubes [85]. Brady et al. studied the $S$. aureus biofilm, formed on a cochlear implant resistant to all conventional antimicrobials, but 5\% TTO completely eradicated it in one hour [86]. Recently, Malic et al. studied the antimicrobial activities of TTO, comparatively to terpinene, eucalyptol (1,8-cineole) and eugenol against $p$. mirabilis involved in catheter-associated urinary tract infections, for further use to obtain modified catheter biomaterials, but they found a reduced antibiofilm activity [87]. Previously, a study from 2010 showed that the pomelo EO inhibited the S. epidermidis and P. aeruginosa biofilms development on soft contact lenses in a time and temperature-dependent manner [88]. In their study, Selim 
et al. presented the Cupressus sempervirens EO inhibitory effect on K. pneumoniae cells adherence capacity to intravenous infusion tubes made of polyvinyl chloride (PVC) at $500 \mu \mathrm{g}$ concentration. It was observed that biomaterial surface pretreatment with EO rendered it repellent the microbial cells, thereby reducing surface adhesion [12]. C. citratus (at $0.5 \times$ and $0.25 \times$ MIC) and Syzygium aromaticum EOs inhibited the C. albicans clinical and reference strains biofilms formed under static conditions in polystyrene tubes [89,90], proposing them as an alternative to amphotericin B and fluconazole [91]. Cinnamon bark EO (containing as major components cinnamaldehyde and eugenol) has been shown to exhibit a potent antibiofilm on P. aeruginosa, reducing it by up to $96 \%$. When mixed with $2 \%$ poly(D,L-lactide-co-glycolide) (PLGA) (a biodegradable polymer), it prevented $p$ biofilm formation [92]. In their paper, Chmitet al. reported that they could not determine a notable antibiofilm effect of the EO from Laurus nobilis using a S. epidermidis strain. Despite these results, the L. nobilis EO remains in attention due to its large spectrum of activity against pathogenic bacteria $[93,94]$. The medical industry is in a constant search for new materials, but also of biocidal products, the potential applications of EOs and polymer systems attracting the attention of researchers. Nostro et al. incorporated eugenol, citronellol and linalool in poly(ethylene-co-vinyl acetate) copolymer (EVA) and tested against E. coli, P. aeruginosa, L. monocytogenes, S. epidermidis, and $S$. aureus. The EO diffused through the polymeric matrix, and the combinations EVA + citronellol and EVA + eugenol at 7\% concentration induced a 40-90\% biofilm decrease [95].

\subsection{EOs Used in Food Industry}

In the food industry, bacteria adhere to vats, tanks and tubes, impairing food safety and quality. Therefore, strategies are needed to inhibit biofilm formation or the elimination of mature biofilms. Current strategies used in the food industry, such as disinfection, surface preconditioning, ultrasonication, etc., although effective, cannot control microbial biofilms. The quorum-sensing systems that assure a coordinate gene expression depending on cellular density also regulating biofilm formation represent a promising lead for the development of novel antibiofilm strategies [96]. The food-contact surfaces rise many problems to the meat industry because of the risk of contamination with pathogenic (e.g., Salmonella enterica, L. monocytogenes, E. coli) ormeat spoilage bacteria (e.g., Pseudomonas spp., Brochothrix thermosphacta and Lactobacillus spp.) bacteria, predominantly growing in biofilms. Disinfection of the food contact surfaces is a difficult and challenging problem that can be solved by finding new disinfectants, such as EOs $[6,97,98]$. To find new food preservatives, detergents and sanitizers, which can be used in the food industry, Chorianopoulos et al. tested the $S$. thymbra EO $(1 \% v / v)$ against monospecific or polyspecific biofilms formed by Gram-positive (S. simulans, L. fermentum, L. monocytogenes) or Gram-negative (P. putida, S. enterica) bacteria. The strong inhibitory effect of EO on microorganisms was associated with carvacrol and thymol compounds, acting as membrane permeabilizing agents [99]. Mentha piperita, C. citratus and Cinnamomum zeylanicum EOs inhibited S. enterica-serotype Enteritidis biofilm development on stainless steel surfaces, for the first two EOs, after 1040 min [100]. Sub-MIC concentrations of cinnamon EO and cinnamaldehyde reduced the biofilm counts at 156-234 $\mu \mathrm{g} / \mathrm{mL}$. Cinnamaldehyde is probably acting by inhibiting the macromolecules synthesis and damaging the cell membrane [101]. The C. citratus EO was also tested comparing with the T. vulgaris EO against $A$. hydrophila biofilm development on stainless steel coupons in UHT skimmed milk [11]. The Thymbra capitata EO was evaluated against both planktonic and biofilm cells of $S$. enterica serovar Typhimurium and proved very efficient in comparison with benzalkonium chloride [102]. One of the proposed alternatives to overcome the bacterial contamination of the food, both in suspension and in the biofilm, can be the use of a mixture of essential components of volatile oils (thymol, eugenol, berberine and cinnamaldehyde), to create a synergistic effect with streptomycin, useful in controlling foodborne pathogens [103]. The antimicrobial activity of 19 EOs was evaluated to determine their effectiveness in eliminating the pathogenic agent $S$. aureus from the food processing plants. Thus, planktonic cells of $S$. aureus strains have shown 
increased sensitivity to volatile thyme, lemon and vetiver oils. The $48 \mathrm{~h}$ old biofilms of the same strains, formed on stainless steel installations in the food industry, could not be eliminated by the volatile oils tested, with increased efficiency of oils of thyme and patchouli. The efficiency of thyme oil was increased by the use of benzalkonium chloride. To prevent the emergence of resistant strains, it is necessary to combine different types of essential oils, as well as their use in combination with various biocides [32].

\subsection{EOs as Air Disinfectants}

Laird et al. examined how Citri-V, a mixture of citrus EOs (orange: bergamot, 1:1 v/v), removes Enterococcus spp. and $S$. aureus biofilms from then stainless steel and plastic surfaces after aerial release in a concentration of $15 \mathrm{mg} / \mathrm{L}$. The citrus vapors may be used for additional decontamination if they are also used with routine cleaning, as they are less toxic than ozone or hydrogen peroxide used for air decontamination treatments [104].

\subsection{Nanoparticles with EOs Used in Controlling and Preventing Infections}

Nanoparticles used in antibiofilm therapy have been intensively studied lately due to their unique properties, helping to fight resistant infections because they can easily penetrate the biofilm matrix and can also functionalize biomedical surfaces by coating, impregnating or embedding, thus preventing biofilm formation [105].

The use of functionalized nanoparticles with EOs can be a method for controlling and preventing infections associated with microbial biofilms, limiting at the same time the consumption of synthetic antimicrobial drugs and thus, reducing microbial resistance.

Nanoparticles can be used ascontrolled and local delivery systems for EOs and also for enhancing their activity. The development of combinations between nanoparticles and EOs is a new research direction approached also by Chifiriuc et al., who used Rosmarinus officinalis EO to obtain a nanobiosystem used for coating catheter surface that successfully inhibited the adherence of $C$. tropicalis and C. albicans clinical strains. After $48-72 \mathrm{~h}$, the biofilm was almost absent on the surface of the coated materials [106].

As we also presented in this paper, many studies have shown the beneficial effect of carvacrol in inhibiting microbial biofilms, attracting the attention of researchers in the field of nanotechnology, which have tried to encapsulate this EO in PLGA nanocapsules to obtain a new drug delivery system, that altered the architecture of the $S$. epidermidis biofilm when added in the initial phases of biofilm formation [107].

The aim of a study performed by Bilcu and coworkers figured out the characteristics resulted from combining the antimicrobial activity of three EOs obtained from Pogostemon cablin, Vanilla planifolia and Cananga odorata subsp. with that of iron oxide@C14 nanoparticles for obtaining coatings for the surfaces of medical devices. These hybrid coatings inhibited the S. aureus and K. pneumoniae adherence and biofilm formation in both initial and maturation (in the case of vanilla EO) phases [108].

Polylactic acid (PLA) nanoparticles with EOs can be used to design new ecological strategies based on natural alternatives efficiently in the treatment of severe infections with biofilms formed by pathogenic and/or resistant bacteria. PLA was combined with lemon EO to obtain functional nanocapsules that exhibited better antimicrobial activity than PLA alone [109]. Using a solvent evaporation method and coated with matrix-assisted pulsed laser evaporation (MAPLE), a hybrid nanocoating composed ofmagnetite nanoparticles functionalized with Melissa officinalis EO, PLA and chitosan, was obtained and characterized. In vitro experiments revealed significant inhibitory activity of prokaryotic cell adhesion properties [110]. New research has been effectuated on the development of nanoemulsions containing geranium oil that demonstrated inhibitory effect against C. albicans, C. tropicalis, C. glabrata and C. krusei biofilms, quantified by measuring the total protein and bioluminescence. The results showed a better activity on C. albicans and C. tropicalis biofilms. Both geranium oil and nanoemulsions containing this oil significantly inhibited biofilm formation in all species tested on polyethylene surfaces, with nanoemulsions having a better activity, proving that they can become an effective alternative for reducing the 
microbial adhesion on the surface of the medical devices and preventing consecutive infections [111]. For increasing its thermal stability, carvacrol is incorporated into polymers of the type of halloysite nanotubes, which then allow subsequent mixing with the low-density polyethylene melt. The nanocomposites exhibited antimicrobial activity against $E$. coli, $L$. innocua and Alternaria alternate biofilms. They have proven effective and can be excellent candidates for a wide range of applications, such as controlling microbial contamination of food [112].

Table 1. The EOs studied in terms of microbial antibiofilm action.

\begin{tabular}{|c|c|c|c|}
\hline $\begin{array}{l}\text { Latin Name of Plant Source } \\
\text { of EO }\end{array}$ & Main Components of EO & $\begin{array}{l}\text { Microbial Strain That } \\
\text { Produces Biofilms on Which } \\
\text { the EO Has Been Tested }\end{array}$ & Reference \\
\hline $\begin{array}{l}\text { Boswellia papyrifera } \\
\text { Boswellia rivae }\end{array}$ & $\begin{array}{l}\text { n-octyl acetate, octanol, limonene, a-pinene, } \\
\text { verticilla-4 (20), 7,11-triene, acetate, incensole }\end{array}$ & $\begin{array}{l}\text { Staphylococcus epidermidis } \\
\text { S. aureus } \\
\text { C. albicans }\end{array}$ & [31] \\
\hline Butia capitata & $\begin{array}{l}\text { capric, caprylic, lauric, linoleic, myristic, oleic, } \\
\text { palmitic, stearic acids }\end{array}$ & $\begin{array}{l}\text { Aciduric bacteria } \\
\text { Lactobacilli } \\
\text { Streptococcus mutans }\end{array}$ & [78] \\
\hline $\begin{array}{l}\text { Cananga odorata } \\
\text { subsp. Genuine } \\
\text { (ylang-ylang oil) }\end{array}$ & $\begin{array}{l}p \text {-cresyl methyl ether, linalool, geranyl acetate, } \\
\text { geraniol, eucalyptol }\end{array}$ & $\begin{array}{l}\text { S. aureus } \\
\text { Klebsiella pneumoniae }\end{array}$ & [109] \\
\hline $\begin{array}{l}\text { Cinnamomum aromaticum } \\
\text { (Cassia oil) }\end{array}$ & cinnamaldehyde, eugenol, linalool & $\begin{array}{l}\text { P. aeruginosa } \\
\text { P. putida } \\
\text { S. aureus }\end{array}$ & [7] \\
\hline Cinnamomum zeylanicum & e-cinnamaldehyde & Salmonella Saintpaul & [102] \\
\hline Citrus hystrix & citronellal & $\begin{array}{l}\text { S. sanguinis } \\
\text { S. mutans }\end{array}$ & [75] \\
\hline Coriandrum sativum & $\begin{array}{l}\text { decanal, trans-2-decenal, 2-decen-1-ol, } \\
\text { cyclodecane }\end{array}$ & $\begin{array}{l}\text { C. albicans } \\
\text { C. tropicalis } \\
\text { C. krusei } \\
\text { C. dubliniensis } \\
\text { C. rugosa }\end{array}$ & [82] \\
\hline Cupressus sempervirens & $\alpha$-pinene, $\alpha$-terpinolene, $\delta$-3-carene, limonene & K.pneumoniae & [12] \\
\hline Curcuma longa & $\begin{array}{l}\text { curlone, trans- } \beta \text {-elemenone, germacrone, } \\
\beta \text {-sesquiphellandrene, } \alpha \text {-turmerone, } \\
\alpha r \text {-turmerone, } \alpha \text {-zingiberene }\end{array}$ & S. mutans & [77] \\
\hline $\begin{array}{l}\text { Cymbopogon citratus } \\
\text { (lemongrass oil) }\end{array}$ & geranial, neral, myrcene & $\begin{array}{l}\text { C. albicans } \\
\text { C. tropicalis } \\
\text { C. glabrata } \\
\text { C. krusei } \\
\text { P. gingivalis } \\
\text { P. intermedia } \\
\text { Aeromonas hydrophila }\end{array}$ & $\begin{array}{l}{[89-91]} \\
{[73]} \\
{[11]}\end{array}$ \\
\hline $\begin{array}{l}\text { Eucalyptus } \\
\text { camaldulensis }\end{array}$ & eucalyptol & $\begin{array}{l}\text { Porphyromonas gingivalis } \\
\text { Actinobacillus } \\
\text { actinomycetemcomitans } \\
\text { Fusobacterium nucleatum } \\
\text { S. mutans } \\
\text { S. sobrinus } \\
\text { C. albicans }\end{array}$ & {$[73]$} \\
\hline
\end{tabular}


Table 1. Cont.

\begin{tabular}{|c|c|c|c|}
\hline $\begin{array}{l}\text { Latin Name of Plant Source } \\
\text { of EO }\end{array}$ & Main Components of EO & $\begin{array}{l}\text { Microbial Strain That } \\
\text { Produces Biofilms on Which } \\
\text { the EO Has Been Tested }\end{array}$ & Reference \\
\hline $\begin{array}{l}\text { Eugenia caryophyllata } \\
\text { (Syzygium aromaticum) } \\
\text { (clove oil) }\end{array}$ & $\begin{array}{l}\text { biflorin, caryophyllene oxide, eugenol, eugenyl } \\
\text { acetate, ellagic acid, gallic acid, kaempferol, } \\
\text { myricetin, oleanolic acid, rhamnocitrin }\end{array}$ & $\begin{array}{l}\text { C. albicans } \\
\text { C. tropicalis } \\
\text { C. glabrata } \\
\text { C. krusei } \\
\text { P. gingivalis } \\
\text { P. intermedia }\end{array}$ & {$[73,89-91]$} \\
\hline Laurus nobilis & $\begin{array}{l}\text { acetate, eucalyptol, linalool, methyleugenol, } \\
\alpha \text {-terpinyl }\end{array}$ & S. epidermidis & {$[93,94]$} \\
\hline $\begin{array}{l}\text { Lavandula angustifolia } \\
\text { (lavender essential oil, LEO) }\end{array}$ & $\begin{array}{l}\text { camphor, caryophyllene, eucalyptol, lavendulyl } \\
\text { acetate, limonene, linalool, linalyl acetate, } \\
\text { cis-ocimene, 3-octanone, a-pinene, transocimene, } \\
\text { terpinen-4-ol }\end{array}$ & $\begin{array}{l}\text { S. aureus } \\
\text { E. coli }\end{array}$ & {$[5]$} \\
\hline $\begin{array}{l}\text { Matricaria chamomilla } \\
\text { (Chamomile EO) }\end{array}$ & $\begin{array}{l}(\mathrm{E}) \text { - } \beta \text {-farnesene } \\
\alpha \text {-bisabolol oxide A }\end{array}$ & $\begin{array}{l}\text { S. mutans } \\
\text { S. sobrinus } \\
\text { Lactobacillus sp. }\end{array}$ & {$[71]$} \\
\hline $\begin{array}{l}\text { Melaleuca alternifolia } \\
\text { (tea tree oil, TTO) }\end{array}$ & $\begin{array}{l}\alpha \text {-pinene, } p \text {-cymene, eucalyptol,terpinen-4-ol, } \\
\gamma \text {-terpinene, } \alpha \text {-terpinene, terpinolene }\end{array}$ & $\begin{array}{l}\text { S. mutans } \\
\text { Proteus mirabilis }\end{array}$ & $\begin{array}{l}{[52]} \\
{[87]}\end{array}$ \\
\hline $\begin{array}{l}\text { Melissa officinalis } \\
\text { (Melissa essential oil, MEO or } \\
\text { lemon balm) }\end{array}$ & $\begin{array}{l}\text { citrals (geranial + neral, citronellal, limonene, } \\
\text { geraniol, } \beta \text {-caryophyllene, } \beta \text {-caryophyllene } \\
\text { oxide, and germacrene D }\end{array}$ & $\begin{array}{l}\text { S. aureus } \\
\text { E. coli }\end{array}$ & {$[5]$} \\
\hline Mentha piperita & $\begin{array}{l}\text { menthofuran, menthol, menthyl acetate, } \\
\text { eucalyptol, menthone, } \alpha \text {-pinene, sabinene, } \\
\beta \text {-pinene }\end{array}$ & $\begin{array}{l}\text { C. albicans } \\
\text { C. dubliniensis }\end{array}$ & [34] \\
\hline Mentha spicata & carvone, trans-carveol, myrcenecarvyl-acetate- $Z$ & S. mutans & {$[73,98]$} \\
\hline $\begin{array}{l}\text { Ocimum } \\
\text { gratissimum }\end{array}$ & eugenol, 1,8-cineole & $\begin{array}{l}\text { S. aureus } \\
\text { E. coli }\end{array}$ & [13] \\
\hline $\begin{array}{l}\text { Origanum vulgare } \\
\text { (oregano oil) }\end{array}$ & carvacrol, thymol, $\gamma$-terpinene, $p$-cymene & $\begin{array}{l}\text { S. aureus } \\
\text { S. epidermidis }\end{array}$ & [55] \\
\hline $\begin{array}{l}\text { Pogostemon cablin } \\
\text { (patchouli essential oil) }\end{array}$ & $\begin{array}{l}\alpha \text {-guaiene, } \beta \text {-caryophyllene, } \\
\delta \text {-cadinene, pogostol, (-)-patchoulol, seychellene, } \\
\alpha \text { - and } \\
\beta \text {-patchoulene }\end{array}$ & $\begin{array}{l}\text { S. aureus } \\
\text { K. pneumoniae }\end{array}$ & [109] \\
\hline $\begin{array}{l}\text { Rosmarinus officinalis } \\
\text { (rosemary oil) }\end{array}$ & $\begin{array}{l}\text { eucalyptol, alpha-pinene, camphor, verbenone, } \\
\text { borneol }\end{array}$ & S. sobrinus & [73] \\
\hline Satureja thymbra & carvacrol, thymol, $p$-cymene & $\begin{array}{l}\text { S. simulans } \\
\text { Lactobacillus fermentum } \\
\text { P. putida } \\
\text { Salmonella enterica } \\
\text { Listeria monocytogenes }\end{array}$ & [6] \\
\hline Thymbra capitata & carvacrol, $\gamma$-terpinene, $p$-cymene & $\begin{array}{l}\text { Candida albicans } \\
\text { C. glabrata } \\
\text { C. tropicalis } \\
\text { C. parapsilosis } \\
\text { C. guilliermondii }\end{array}$ & [44] \\
\hline $\begin{array}{l}\text { Thymus vulgaris } \\
\text { (thyme oil) }\end{array}$ & eucalyptol, camphor & A. hydrophila & [11] \\
\hline $\begin{array}{l}\text { Vanilla planifolia } \\
\text { (vanilla oil) }\end{array}$ & $\begin{array}{l}\text { ethylvanillin, 4-hydroxybenzaldehyde, methyl } \\
\text { anisate, 4-hydroxybenzyl methyl ether, } \\
\text { piperonal, vanillic acid, vanillin }\end{array}$ & $\begin{array}{l}\text { S. aureus } \\
\text { K. pneumoniae }\end{array}$ & [109] \\
\hline
\end{tabular}


Table 2. The EOs studied in terms of microbial antibiofilm action formed on a medical device or live surface.

\begin{tabular}{|c|c|c|}
\hline $\begin{array}{l}\text { Latin Name of Plant Source } \\
\text { of EO }\end{array}$ & $\begin{array}{c}\text { The Support (Medical Device) on Which the } \\
\text { Biofilm Was Studied }\end{array}$ & Reference \\
\hline Baccharis dracunculifolia & \multirow{3}{*}{ Dental biofilm } & [76] \\
\hline Mentha spicata & & [73] \\
\hline Melaleuca alternifolia & & [52] \\
\hline Cananga odorata subsp. genuine & \multirow{3}{*}{ Catheter } & \multirow{3}{*}{ [109] } \\
\hline Pogostemoncablin & & \\
\hline Vanilla planifolia & & \\
\hline Cupressus sempervirens & Intravenous infusion tube & [12] \\
\hline Cymbopogon citratus & \multirow{3}{*}{ Stainless steel coupons } & [11] \\
\hline Thymus vulgaris & & [11] \\
\hline Saturejathymbra & & [6] \\
\hline Eugenia caryophyllata & \multirow{3}{*}{ Soft contact lenses } & \multirow{3}{*}{ [33] } \\
\hline (Syzygiumaromaticum) & & \\
\hline Thymus vulgaris & & \\
\hline Lavandula angustifolia & \multirow{3}{*}{ Urological catheter, infusion tube, surgical mesh } & \multirow{3}{*}{ [5] } \\
\hline Melissa officinalis & & \\
\hline Melaleuca alternifolia & & \\
\hline \multirow{3}{*}{ Melaleuca alternifolia } & Catheter-associated urinary tract infections & [87] \\
\hline & Cochlear implant & [86] \\
\hline & Silicone tympanostomy tubes & [85] \\
\hline
\end{tabular}

\section{Conclusions}

Essential oils represent safe and efficient alternatives for the development of novel antibiofilm agents that could find a potential role in the medical and food industries for infection control, especially BAIs associated with artificial medical devices, susceptible to the formation of microbial films resistant to conventional antibiotic treatment. The great advantage of EOs is that their usage is not likely to select for microbial resistance because they have a complex composition and, therefore, multiple targets in the microbial cells.

An increasing idea to combat microbial biofilms is to combine the conventional antimicrobials with EOs, based on studies already conducted, which have shown promising results.

Our review shows that most studies were performed in vitro, thus further in vivo studies are necessary, as well as the elucidation of many additional therapeutic aspects, such as EOs formulation, frequency and duration of therapy, safety issues; these aspects need to be optimized to ensure the best possible clinical outcomes.

It cannot be neglected the potential advantage of using EOs prophylactically, and in this context, a promising lead is to obtain bioactive nanobiocoatings containing EOs for inhibiting bacterial and fungal adhesion and further biofilm development on the different surface from the medical, industrial and natural environment.

Author Contributions: Conceptualization, D.C.N. and C.L.; methodology, I.Z.; software, C.C. and I.N.; investigation, T.C. and P.I.; data curation, D.C.N., C.L., M.C.C. and I.Z.; writing-original draft preparation, D.C.N., C.L., C.C., M.C.C., T.C., P.I., I.N. and I.Z.; writing-review and editing, D.C.N., M.C.C. and P.I.; visualization, T.C.; supervision, D.C.N., C.L. and I.Z. All authors have read and agreed to the published version of the manuscript.

Funding: This research was funded by UEFISCDI, PN-III-P1-1.1-TE-2019-1506, project number 147TE/2020.

Institutional Review Board Statement: Not applicable. 
Informed Consent Statement: Not applicable.

Data Availability Statement: Not applicable.

Conflicts of Interest: The authors declare no conflict of interest.

\section{References}

1. Rodney, M.D.; Costerton, J.W. Biofilms: Survival Mechanisms of Clinically Relevant Microorganisms. Clin. Microbiol. Rev. 2002, 15, 167-193.

2. Mohammadi, Z.; Palazzi, F.; Giardino, L.; Shalavi, S. Microbial biofilms in endodontic infections: An update review. Biomed. J. 2013, 36, 59-70. [CrossRef] [PubMed]

3. Lazăr, V.; Chifiriuc, M.C. Medical significance and new therapeutical strategies for biofilm associated infections. Roum. Arch. Microbiol. Immunol. 2010, 69, 125-138. [PubMed]

4. Glinel, K.; Thebault, P.; Humblot, V.; Pradier, C.M.; Jouenne, T. Antibacterial surfaces developed from bio-inspired approaches. Acta Biomater. 2012, 8, 1670-1684. [CrossRef]

5. Budzyñska, A.; Wiêckowska-Szakiel, M.; Sadowska, B.; Kalemba, D.; Rózalska, B. Antibiofilm Activity of Selected Plant Essential Oils and their Major Components. Pol. J. Microbiol. 2011, 60, 35-41. [CrossRef] [PubMed]

6. Chorianopoulos, N.G.; Giaouris, E.D.; Skandamis, P.N.; Haroutounian, S.A.; Nychas, G.J.E. Disinfectant test against monoculture and mixed-culture biofilms composed of technological, spoilage and pathogenic bacteria: Bactericidal effect of essential oil and hydrosol of Satureja thymbra and comparison with standard acid-base sanitizers. J. Appl. Microbiol. 2008, 104, 1586-1596. [CrossRef]

7. Kavanaugh, N.L.; Ribbeck, K. Selected Antimicrobial Essential Oils Eradicate Pseudomonas spp. and Staphylococcus aureus Biofilms. Appl. Environ. Microbiol. 2012, 78, 4057-4061. [CrossRef] [PubMed]

8. Burt, S. Essential oils: Their antibacterial properties and potential applications in foods-A review. Int. J. Food Microbiol. 2004, 94, 223-253. [CrossRef] [PubMed]

9. Bakkali, F.; Averbeck, S.; Averbeck, D.; Idaomar, M. Biological effects of essential oils-A review. Food Chem. Toxicol. 2008, 46, 446-475. [CrossRef]

10. Saviuc, C.M.; Drumea, V.; Olariu, L.; Chifiriuc, M.C.; Bezirtzoglou, E.; Lazăr, V. Essential Oils with Microbicidal and Antibiofilm Activity. Curr. Pharm. Biotechnol. 2015, 16, 137-151. [CrossRef]

11. Millezi, A.F.; das Graças Cardoso, M.; Alves, E.; Piccoli, R.H. Reduction of Aeromonas hidrophyla biofilm on stainless stell surface by essential oils. Braz. J. Microbiol. 2013, 44, 73-80. [CrossRef] [PubMed]

12. Selim, S.A.; Adam, M.E.; Hassan, S.M.; Albalawi, A.R. Chemical composition, antimicrobial and antibiofilm activity of the essential oil and methanol extract of the Mediterranean cypress (Cupressus sempervirens L.). BMC Complement. Altern. Med. 2014, 14, 179. [CrossRef]

13. Melo, R.S.; Albuquerque Azevedo, Á.M.; Gomes Pereira, A.M.; Rocha, R.R.; Bastos Cavalcante, R.M.; Carneiro Matos, M.N.; Ribeiro Lopes, P.H.; Gomes, G.A.; Soares Rodrigues, T.H.; Santos, H.S.d.; et al. Chemical Composition and Antimicrobial Effectiveness of Ocimum gratissimum L. Essential Oil Against Multidrug-Resistant Isolates of Staphylococcus aureus and Escherichia coli. Molecules 2019, 24, 3864. [CrossRef] [PubMed]

14. Tang, C.; Chen, J.; Zhang, L.; Zhang, R.; Zhang, S.; Ye, S.; Zhao, Z.; Yang, D. Exploring the antibacterial mechanism of essential oils by membrane permeability, apoptosis and biofilm formation combination with proteomics analysis against methicillin-resistant Staphylococcus aureus. Int. J. Med. Microbiol. 2020, 5, 151435. [CrossRef] [PubMed]

15. Das, S.; Horváth, B.; Šafranko, S.; Jokić, S.; Széchenyi, A.; Kőszegi, T. Antimicrobial Activity of Chamomile Essential Oil: Effect of Different Formulations. Molecules 2019, 24, 4321. [CrossRef] [PubMed]

16. Fde, O.P.; Mendes, J.M.; Lima, I.O.; Mota, K.S.; Oliveira, W.A.; Ede, O.L. Antifungal activity of geraniol and citronellol, two monoterpenes alcohols, against Trichophyton rubrum involves inhibition of ergosterol biosynthesis. Pharm. Biol. 2015, 53, 228-234.

17. Ortega-Ramirez, L.A.; Gutiérrez-Pacheco, M.M.; Vargas-Arispuro, I.; González-Aguilar, G.A.; Martínez-Téllez, M.A.; AyalaZavala, J.F. Inhibition of Glucosyltransferase Activity and Glucan Production as an Antibiofilm Mechanism of Lemongrass Essential Oil against Escherichia coli O157:H7. Antibiotics 2020, 9, 102. [CrossRef] [PubMed]

18. Das, S.; Vörös-Horváth, B.; Bencsik, T.; Micalizzi, G.; Mondello, L.; Horváth, G.; Kőszegi, T.; Széchenyi, A. Antimicrobial Activity of Different Artemisia Essential Oil Formulations. Molecules 2020, 25, 2390. [CrossRef]

19. Pina-Barrera, A.M.; Alvarez-Roman, R.; Baez-Gonzalez, J.G.; Amaya-Guerra, C.A.; Rivas-Morales, C.; Gallardo-Rivera, C.T.; Galindo-Rodriguez, S.A. Application of a multisystem coating based on polymeric nanocapsule containing essential oil of Thymus vulgaris L. to increase the shelf life of table grapes (Vitis vinifera L.). IEEE Trans. NanoBioscience 2019, 18, 549-557. [CrossRef]

20. Alizadeh Behbahani, B.; Tabatabaei Yazdi, F.; Vasiee, A.; Mortazavi, S.A. Oliveria decumbens essential oil: Chemical compositions and antimicrobial activity against the growth of some clinical and standard strains causing infection. Microb. Pathog. 2018, 114, 449-452. [CrossRef] [PubMed]

21. Tang, X.; Shao, Y.-L.; Tang, Y.-J.; Zhou, W.-W. Antifungal Activity of Essential Oil Compounds (Geraniol and Citral) and Inhibitory Mechanisms on Grain Pathogens (Aspergillus flavus and Aspergillus ochraceus). Mol. J. Synth. Chem. Nat. Prod. Chem. 2018, $23,2108$. [CrossRef] 
22. Inouye, S.; Tsuruoka, T.; Uchida, K.; Yamaguchi, H. Effect of Sealing and Tween 80 on the Antifungal Susceptibility Testing of Essential Oils. Microbiol. Immunol. 2001, 45, 201-208. [CrossRef] [PubMed]

23. Abarca, R.L.; Rodríguez, F.J.; Guarda, A.; Galotto, M.J.; Bruna, J.E. Characterization of beta-cyclodextrin inclusion complexes containing an essential oil component. Food Chem. 2016, 196, 968-975. [CrossRef] [PubMed]

24. Wang, T.; Li, B.; Si, H.; Lin, L.; Chen, L. Release characteristics and antibacterial activity of solid state eugenol/ $\beta$-cyclodextrin inclusion complex. J. Incl. Phenom. Macrocycl. Chem. 2011, 71, 207-213. [CrossRef]

25. Astray, G.; Gonzalez-Barreiro, C.; Mejuto, J.C.; Rial-Otero, R.; Simal-Gándara, J. A review on the use of cyclodextrins in foods. Food Hydrocoll. 2009, 23, 1631-1640. [CrossRef]

26. Zhou, Y.; Sun, S.; Bei, W.; Zahi, M.R.; Yuan, Q.; Liang, H. Preparation and antimicrobial activity of oreganoessential oil Pickering emulsion stabilized by cellulose nanocrystals. Int. J. Biol. Macromol. 2018, 112, 7-13. [CrossRef]

27. Halcón, L.; Milkus, K. Staphylococcus aureus and wounds: A review of tea tree oil as a promising antimicrobial. Am. J. Infect. Control. 2004, 32, 4002-4008. [CrossRef]

28. Karpanen, T.J.; Worthington, T.; Hendry, E.R.; Conway, B.R.; Lambert, P.A. Antimicrobial efficacy of chlorhexidine digluconate alone and in combination with eucalyptus oil, tea tree oil and thymol against planktonic and biofilm cultures of Staphylococcus epidermidis. J. Antimicrob. Chemother. 2008, 62, 1031-1036. [CrossRef]

29. Kwiecinski, J.; Eick, S.; Wojcik, K. Effects of tea tree (Melaleuca alternifolia) oil on Staphylococcus aureus in biofilms and stationary growth phase. Int. J. Antimicrob. Agents 2009, 33, 343-347. [CrossRef]

30. Sudjana, A.N.; Carson, C.F.; Carson, K.C.; Riley, T.V.; Hammer, K.A. Candida albicans adhesion to human epithelial cells and polystyrene and formation of biofilm is reduced by sub-inhibitory Melaleuca alternifolia (tea tree) essential oil. Med. Mycol. 2012, 50, 863-870. [CrossRef]

31. Schillaci, D.; Arizza, V.; Dayton, T.; Camarda, L.; Di Stefano, V. In vitro anti-biofilm activity of Boswellia spp. oleogum resin essential oils. Lett. Appl. Microbiol. 2008, 47, 433-438. [CrossRef] [PubMed]

32. Vázquez-Sánchez, D.; Cabo, M.L.; Rodríguez-Herrera, J.J. Antimicrobial activity of essential oils against Staphylococcus aureus biofilms. Food Sci. Technol. Int. 2014, 21, 559-570. [CrossRef] [PubMed]

33. Olivier, E.I. Antimicrobial activities of selected essential oils against Fusarium oxysporum isolates and their biofilms. S. Afr. J. Bot. 2015, 99, 115-121.

34. Saharkhiz, M.J.; Motamedi, M.; Zomorodian, K.; Pakshir, K.; Miri, R.; Hemyari, K. Chemical Composition, Antifungal and Antibiofilm Activities of the Essential Oil of Mentha piperita L. ISRN Pharm. 2012, 2012, 718645. [CrossRef] [PubMed]

35. Lee, K.; Lee, J.H.; Kim, S.I.; Cho, M.H.; Lee, J. Anti-biofilm, anti-hemolysis, and anti-virulence activities of black pepper, cananga, myrth oils, and nerolidol against Staphylococcus aureus. Appl. Microbiol. Biotechnol. 2014, 98, 9447-9457. [CrossRef] [PubMed]

36. Gursoy, U.K.; Gursoy, M.; Gursoy, O.V.; Cakmakci, L.; Könönen, E.; Uitto, V.J. Anti-biofilm properties of Satureja hortensis L. essential oil against periodontal pathogens. Anaerobe 2009, 15, 164-167. [CrossRef] [PubMed]

37. Gomes, F.; Teixeira, P.; Cerca, N.; Azeredo, J.; Oliveira, R. Effect of Farnesol on Structure and Composition of Staphylococcus epidermidis Biofilm Matrix. Curr. Microbiol. 2011, 63, 354-359. [CrossRef] [PubMed]

38. Sepahi, E.; Tarighi, S.; Ahmadi, F.S.; Bagheri, A. Inhibition of quorum sensing in Pseudomonas aeruginosa by two herbal essential oils from Apiaceae family. J. Microbiol. 2015, 53, 176-180. [CrossRef]

39. Pratiwi, S.U.T.; Lagendijk, E.L.; de Weert, S.; Idroes, R.; Hertiani, T.; Van den Hondel, C. Effect of Cinnamomum burmannii Nees ex Bl. and Massoiaaromatica Becc. Essential oils on planktonic growth and biofilm formation of Pseudomonas aeruginosa and Staphylococcus aureus In Vitro. Int. J. Appl. Res. Nat. Prod. 2015, 8, 1-13.

40. Camporese, A. In vitro activity of Eucalyptus smithii and Juniperus communis essential oils against bacterial biofilms and efficacy perspectives of complementary inhalation therapy in chronic and recurrent upper respiratory tract infections. Infez Med. 2013, 2, 117-124.

41. Benbelaïd, F.; Khadir, A.; Abdoune, M.A.; Bendahou, M.; Muselli, A.; Costa, J. Antimicrobial activity of some essential oils against oral multidrugresistant Enterococcus faecalis in both planktonic and biofilm state. Asian Pac. J. Trop. Biomed. $2014,4,463-472$. [CrossRef]

42. Negreiros, M.; Pawlowski, Â.; Zini, C.A.; Soares, G.L.G.; Motta, A.; Frazzon, A.P.G. Antimicrobial and antibiofilm activity of Baccharis psiadioides essential oil against antibiotic-resistant Enterococcus faecalis strains. Pharm. Biol. 2016, 54, 3272-3279. [CrossRef]

43. Zhou, L.; Zheng, H.; Tang, Y.; Yu, W.; Gong, Q. Eugenol inhibits quorum sensing at sub-inhibitory concentrations. Biotechnol. Lett. 2013, 35, 631-637. [CrossRef]

44. Palmeira-de-Oliveira, A.; Gaspar, C.; Palmeira-de-Oliveira, R.; Silva-Dias, A.; Salgueiro, L.; Cavaleiro, C.; Pina-Vaz, C.; Martinezde-Oliveira, J.; Queiroz, J.A.; Rodrigues, A.G. The anti-Candida activity of Thymbra capitata essential oil: Effect upon pre-formed biofilm. J. Ethnopharmacol. 2012, 140, 379-383. [CrossRef]

45. Dalleau, S.; Cateau, E.; Berges, T.; Berjeaud, J.M.; Imbert, C. In vitro activity of terpenes against Candida biofilms. Int. J. Antimicrob. Agents 2008, 31, 572-576. [CrossRef] [PubMed]

46. Avcioglu, N.H.; Sahal, G.; Bilkay, I.S. Antibiofilm effects of citrus limonum and zingiber officinale oils on biofilm formation of Klebsiella ornithinolytica, Klebsiella oxytoca and klebsiella terrigena species. Afr. J. Tradit. Complement. Altern. Med. 2016, 13, 61-67. [CrossRef] [PubMed] 
47. Kerekes, E.B.; Vidács, A.; Takó, M.; Petkovits, T.; Vágvölgyi, C.; Horváth, G.; Balázs, V.L.; Krisch, J. Anti-Biofilm Effect of Selected Essential Oils and Main Components on Mono- and Polymicrobic Bacterial Cultures. Microorganisms 2015, 7, 345. [CrossRef] [PubMed]

48. Rosato, A.; Sblano, S.; Salvagno, L.; Carocci, A.; Clodoveo, M.L.; Corbo, F.; Fracchiolla, G. Anti-Biofilm Inhibitory Synergistic Effects of Combinations of Essential Oils and Antibiotics. Antibiotics 2020, 9, 637. [CrossRef] [PubMed]

49. Teles, R.P.; Teles, F.R.F. Antimicrobial agents used in the control of periodontal biofilms: Effective adjuncts to mechanical plaque control. Braz. Oral. Res. 2009, 23, 39-48. [CrossRef]

50. Martos, J.; Ferrer Luque, C.M.; González-Rodríguez, M.P.; Arias-Moliz, M.T.; Baca, P. Antimicrobial activity of essential oils and chloroform alone and combinated with cetrimide against Enterococcus faecalis biofilm. Eur. J. Microbiol. Immunol. 2013, 3, 44-48 [CrossRef]

51. Venkateshbabu, N.; Anand, S.; Abarajithan, M.; Sheriff, S.O.; Jacob, P.S.; Sonia, N. Natural therapeutic options in endodontics-A review. Open Dent. J. 2016, 10, 214-226. [CrossRef] [PubMed]

52. Santamaria, M., Jr.; Petermann, K.D.; Vedovello, A.S.; Degan, V.; Lucato, A.; Franzinic, C.M. Antimicrobial effect of Melaleuca alternifolia dental gel in orthodontic patients. Am. J. Orthod. Dentofac. Orthop. 2014, 145, 198-202. [CrossRef] [PubMed]

53. Carson, C.F.; Hammer, K.A.; Riley, T.V. Melaleuca alternifolia (Tea Tree) Oil: A Review of Antimicrobial and Other Medicinal Properties. Clin. Microbiol. Rev. 2006, 19, 50-62. [CrossRef] [PubMed]

54. Smith, K.; Robertson, D.P.; Lappin, D.F.; Ramage, G. Commercial mouth washes are ineffective against oral MRSA biofilms. Oral Med. 2013, 115, 624-629.

55. Stanecu, F.; Bancescu, G.; Constantinescu, M.V.; Defta, C. Microbial biofilm as a form of bacteria high organization and communication. Rom. J. Stomatol. 2012, 58, 284-290.

56. Nostro, A.; SudanoRoccaro, A.; Bisignano, G.; Marino, A.; Cannatelli, M.A.; Pizzimenti, F.C.; Cioni, P.L.; Procopio, F.; Blanco, A.R. Effects of oregano, carvacrol and thymol on Staphylococcus aureus and Staphylococcus epidermidis biofilms. J. Med. Microbiol. 2007, 56, 519-523. [CrossRef]

57. Cortelli, S.C.; Costa, F.O.; Rode, S.; Haas, A.N.; Pintode Andrade, A.K.; Pannuti, C.M.; Escobar, E.C.; de Almeida, E.R.; Cortelli, J.R.; Pedrazzi, V.; et al. Mouthrinserecommendation for prosthodontic patients. Braz. Oral Res. 2014, 28, 1-9. [CrossRef]

58. Marsh, P.D. Controlling the oral biofilm with antimicrobials. J. Dent. 2010, 38, S11-S15. [CrossRef]

59. Haas, A.N.; Pannuti, C.M.; Andrade, A.K.P.; Escobar, E.C.; Almeida, E.R.; Costa, F.O.; Cortelli, J.R.; Cortelli, S.C.; Rode, S.; Pedrazzi, V.; et al. Mouthwashes for the control of supragingival biofilm and gingivitis in orthodontic patients: Evidence-based recommendations for clinicians. Braz. Oral Res. 2014, 28, 1-8. [CrossRef]

60. Quintas, V.; Prada-López, I.; Prados-Frutos, J.C.; Tomás, I. In situ antimicrobial activity on oral biofilm: Essential oils vs. 0.2\% chlorhexidine. Clin. Oral Investig. 2015, 19, 97-107. [CrossRef] [PubMed]

61. Quintas, V.; Prada-López, I.; Donos, N.; Suárez-Quintanilla, D.; Tomás, I. Antiplaque Effect of Essential Oils and 0.2\% Chlorhexidine on an In Situ Model of Oral Biofilm Growth: A Randomised Clinical Trial. PLoS ONE 2015, 10, e0117177. [CrossRef] [PubMed]

62. Erriu, M.; Pili, F.M.G.; Tuveri, E.; Pigliacampo, D.; Scano, A.; Montaldo, C.; Piras, V.; Denotti, G.; Pilloni, A.; Garau, V.; et al. Oil Essential Mouthwashes Antibacterial Activity against Aggregati bacteractinomycetemcomitans: A Comparison between Antibiofilm and Antiplanktonic Effects. Int. J. Dent. 2013, 164267. [CrossRef]

63. Sun, F.C.; Engelman, E.E.; McGuire, J.A. Impact of an Anticaries Mouthrinse on In Vitro Remineralization and Microbial Control. Int. J. Dent. 2014, 2014, 982071. [CrossRef] [PubMed]

64. Rasooli, I.; Shayegh, S.; Taghizadeh, M.; Astaneh, S.D.A. Phytotherapeutic Prevention of Dental Biofilm Formation. Phytother. Res. 2008, 22, 1162-1167. [CrossRef]

65. Hofer, D.; Meier, A.; Sener, B.; Guggenheim, B.; Attin, T.; Schmidlin, P.R. Biofilm reduction and staining potential of a $0.05 \%$ chlorhexidine rinse containing essential oils. Int. J. Dent. Hyg. 2011, 9, 60-67. [CrossRef] [PubMed]

66. Apolonio, J.; Faleiro, M.L.; Miguel, M.G.; Neto, L. No induction of antimicrobial resistance in Staphylococcus aureus and Listeria monocytogenes during continuous exposure to eugenol and citral. FEMS Microbiol. Lett. 2014, 354, 92-101.

67. Bersan, S.M.F.; Galvão, L.C.C.; Goes, V.F.F. Action of essential oils from Brazilian native and exotic medicinal species on oral biofilms. BMC Complement. Altern. Med. 2014, 14, 1-12. [CrossRef] [PubMed]

68. Pedrazzi, V.; Escobar, E.C.; Cortelli, J.R.; Haas, A.N.; Pintode Andrade, A.K.; Pannuti, C.M.; Rodriguesde Almeida, E.; Costa, F.O.; Cortelli, S.C.; de Mello Rode, S. Antimicrobial mouth rinse use as an adjunct method in peri-implant biofilmcontrol. Braz. Oral Res. 2014, 28, 1-9. [CrossRef] [PubMed]

69. Marinković, J.; Ćulafić, D.M.; Nikolić, B.; Đukanović, S.; Marković, T.; Tasić, G.; Ćirić, A.; Marković, D. Antimicrobial potential of irrigants based on essential oils of Cymbopogon martinii and Thymus zygis towards in vitro multispecies biofilm cultured in ex vivo root canals. Arch. Oral Biol. 2020, 117, 104842. [CrossRef]

70. Jongsma, M.A.; van der Mei, H.C.; Atema-Smit, J.; Busscher, H.J.; Ren, Y. In vivo biofilm formation on stainless steel bonded retainers during different oral health-care regimens. Int. J. Oral Sci. 2015, 7, 42-48. [CrossRef]

71. Braga, A.S.; de Melo Simas, L.L.; Pires, J.G.; Martines Souza, B.; de Souza Rosa de Melo, F.P.; Saldanha, L.L.; Dokkedal, A.L.; Magalhães, A.C. Antibiofilm and anti-caries effects of an experimental mouth rinse containing Matricaria chamomilla L. extract under microcosm biofilm on enamel. J. Dent. 2020, 99, 103415. [CrossRef] [PubMed] 
72. Rasooli, I.; Shayegh, S.; Astaneh, S. The effect of Mentha spicata and Eucalyptus camaldulensis essential oils on dental biofilm. Int. J. Dent. Hyg. 2009, 7, 196-203. [CrossRef] [PubMed]

73. Kouidhi, B.; Mohammed, Y.A.; Qurashi, A.L.; Chaieb, K. Drug resistance of bacterial dental biofilm and the potential use of natural compounds as alternative for prevention and treatment. Microb. Pathog. 2015, 80, 39-49. [CrossRef] [PubMed]

74. de Carvalho Galváo, L.C.; Furletti, V.F.; Bersan, S.M.F.; da Cunha, M.G.; Ruiz, A.L.T.G.; Ernesto de Carvalho, J.; Sartoratto, A.; Rehder, V.L.G.; Figueira, G.M.; Duarte, M.C.T.; et al. Antimicrobial activity of essential oils against Streptococcus mutans and their antiproliferative effects. Evid. Based Complement. Altern. Med. 2012. [CrossRef]

75. Wongsariya, K.; Phanthong, P.; Bunyapraphatsara, N.; Srisukh, V.; Chomnawang, M.T. Synergistic interaction and mode of action of Citrus hystrix essential oil against bacteria causing periodontal diseases. Pharm. Biol. 2014, 52, 273-280. [CrossRef]

76. Pedrazzi, V.; Leite, M.F.; Tavares, C.R.; Sato, S.; do Nascimento, G.C.; Issa, J.P.M. Herbal mouthwash containing extracts of Baccharis dracunculifoliaas agent for the control of biofilm: Clinical evaluation in humans. Sci. World J. 2015. [CrossRef]

77. Lee, K.H.; Kim, B.S.; Keum, K.S.; Yu, H.H.; Kim, Y.-H.; Chang, B.-S.; Ra, J.-Y.; Moon, H.-D.; Seo, B.-R.; Choi, N.-Y.; et al. Essential oil of Curcuma longa inhibits Streptococcus mutans biofilm formation. J. Food Sci. 2011, 76. [CrossRef] [PubMed]

78. Peraltaa, S.L.; Carvalhob, P.H.A.; van de Sandea, F.H.; Pereirac, C.M.P.; Pivaa, E.; Lund, R.G. Self-etching dental adhesive containing a natural essential oil: Anti-biofouling performance and mechanical properties. Biofouling 2013, 29, 345-355. [CrossRef] [PubMed]

79. Furletti, V.F.; Teixeira, L.P.; Obando-Pereda, G. Action of Coriandrum sativum L. essential oil upon oral Candida albicans biofilm formation. Evid. Based Complement. Altern. Med. 2011. [CrossRef]

80. Oliveira, S.A.; Zambrana, J.R.; Iorio, F.B.; Pereira, C.A.; Jorge, A.O. The antimicrobial effects of Citrus limonum and Citrus aurantium essential oils on multi-species biofilms. Braz. Oral. Res. 2014, 28, 22-27. [CrossRef]

81. Freires, I.A.; Bueno-Silva, B.; Câmara de Carvalho Galvão, L.; Duarte, M.C.T.; Sartoratto, A.; Figueira, G.M.; de Alencar, S.M.; Rosalen, P.L. The effect of essential oils and bioactive fractions on Streptococcus mutans and Candida albicans biofilms: A confocal analysis. Evid. Based Complement. Altern. Med. 2015. [CrossRef]

82. de Almeida Freires, I.; Murata, R.M.; Furletti, V.F. Coriandrum sativum L. (Coriander) essential oil: Antifungal activity and mode of action on Candida spp., and molecular targets affected in human whole-genome expression. PLoS ONE 2014, 9 , e099086. [CrossRef]

83. Alves, F.R.F.; Neves, M.A.S.; Silva, M.G.; Rôças, I.N.; Siqueira, J.F., Jr. Antibiofilm and antibacterial activities of farnesol and xylitol as potential endodontic irrigants. Braz. Dent. J. 2013, 24, 224-229. [CrossRef] [PubMed]

84. Anghel, I.; Grumezescu, A.M.; Holban, A.M.; Ficai, A.; Anghel, A.G.; Chifiriuc, M.C. Biohybrid nanostructured iron oxide nanoparticles and Satureja hortensis to prevent fungal biofilm development. Int. J. Mol. Sci. 2013, 14, 18110-18123. [CrossRef] [PubMed]

85. Park, H.; Jang, C.H.; Cho, Y.B.; Choi, C.H. Antibacterial effect of Tea-tree oil on methicillin-resistant Staphylococcus aureus biofilm formation of the tympanostomy tube: An in vitro study. In Vivo 2007, 21, 1027-1030.

86. Brady, A.J.; Farnan, T.B.; Toner, J.G.; Gilpin, D.F.; Tunney, M.M. Treatment of a cochlear implant biofilm infection: A potential role for alternative antimicrobial agents. Ann. Otol. Rhinol. Laryngol. 2010, 124, 729-738. [CrossRef]

87. Malic, S.; Jordan, R.P.C.; Waters, M.G.J.; Stickler, D.J.; Williamsa, D.W. Biocide activity against urinary catheter pathogen. Antim. Agents Chemother. 2014, 58, 1192-1194. [CrossRef]

88. Saviuc, C.; Dascălu, L.; Chifiriuc, M.C.; Rădulescu, V.; Oprea, E.; Popa, M.; Hristu, R.; Stanciu, G.; Lazăr, V. The inhibitory activity of pomelo essential oil on the bacterial biofilms development on soft contact lenses. Roum. Arch. Microbiol. Immunol. 2010, 69, $145-152$.

89. Gbenou, J.D.; Ahounou, J.F.; Akakpo, H.B.; Laleye, A.; Yayi, E.; Gbaguidi, F.; Baba-Moussa, L.; Darboux, R.; Dansou, P.; Moudachirou, M.; et al. Phytochemical composition of Cymbopogon citratus and Eucalyptus citriodora essential oils and their anti-inflammatory and analgesic properties on Wistar rats. Mol. Biol. Rep. 2013, 40, 1127-1134. [CrossRef]

90. Nassar, M.I.; Gaara, A.H.; El-Ghorab, A.H.; Farrag, A.-R.H.; Shen, H.; Huq, E.; Mabry, T. Chemical constituents of Clove (Syzygium aromaticum, Fam. Myrtaceae) and their antioxidant activity. Rev Latinoamer. Quím. 2007, 35, 47-57.

91. Khan, M.S.A.; Ahmad, I. Biofilm inhibition by Cymbopogon citratus and Syzygium aromaticum essential oils in the strains of Candida albicans. J. Ethnopharmacol. 2012, 140, 416-423. [CrossRef]

92. Kim, Y.G.; Lee, J.H.; Kim, S.I.; Baek, K.H.; Lee, J. Cinnamon bark oil and its components inhibit biofilm formation and toxin production. Int. J. Food Microbiol. 2015, 195, 30-39. [CrossRef]

93. Chmit, M.; Kanaan, H.; Habib, J.; Abbass, M.; Mcheik, A.; Chokr, A. Antibacterial and antibiofilm activities of polysaccharides, essential oil, and fatty oil extracted from Laurus nobilis growing in Lebanon. Asian Pac. J. Trop. Med. 2014, 7, S546-S552. [CrossRef]

94. Caredda, A.; Marongiu, B.; Porcedda, S.; Soro, C. Supercritical carbon dioxide extraction and characterization of Laurus nobilis essential oil. J. Agric. Food Chem. 2002, 50, 1492-1496. [CrossRef]

95. Nostro, A.; Scaffaro, R.; D'Arrigo, M.; Botta, L.; Filocamo, A.; Marino, A.; Bisignano, G. Development and characterization of essential oil component-based polymer films: A potential approach to reduce bacterial biofilm. Appl. Microbiol. Biotechnol. 2013, 97, 9515-9523. [CrossRef]

96. Coughlan, L.M.; Cotter, P.D.; Hill, C.; Alvarez-Ordóñez, A. New weapons to fight old enemies: Novel strategies for the (bio)control of bacterial biofilms in the food industry. Front. Microbiol. 2016. [CrossRef] 
97. Giaouris, E.; Heir, E.; Hébraud, M.; Chorianopoulos, N.; Langsrud, S.; Møretrø, T.; Habimana, O.; Desvaux, M.; Renier, S.; Nychas, G.J. Attachment and biofilm formation by foodborne bacteria in meat processing environments: Causes, implications, role of bacterial interactions and control by alternative novel methods. Meat Sci. 2014, 97, 298-309. [CrossRef] [PubMed]

98. Znini, M.; Bouklah, M.; Majidi, L.; Kharchouf, S.; Aouniti, A.; Bouyanzer, A.; Hammouti, B.; Costa, J.; Al-Deyab, S.S. Chemical composition and inhibitory effect of Mentha spicata essential oil on the corrosion of steel in molar hydrochloric acid. Int. J. Electrochem. Sci. 2011, 6, 691-704.

99. Gachkar, L.; Yadegari, D.; Rezaei, M.B.; Taghizadeh, M.; Astaneh, S.A.; Rasooli, I. Chemical and biological characteristics of Cuminum cyminum and Rosmarinus officinalis essential oils. Food Chem. 2007, 102, 898-904. [CrossRef]

100. Valeriano, C.; de Oliveira, T.L.C.; de Carvalhoa, S.M.; das Graças Cardoso, M.; Alves, E.; Piccoli, R.H. The sanitizing action of essential oil-based solutions against Salmonella enterica serotype Enteritidis S64 biofilm formation on AISI 304 stainless steel. Food Control 2012, 25, 673-677. [CrossRef]

101. Piovezan, M.; Uchida, N.S.; da Silva, A.F.; Grespan, R.; Santos, P.R.; Silva, E.L.; Cuman, R.K.N.; Machinski Junior, M.; Mikcha, J.M.G. Effect of cinnamon essential oil and cinnamaldehyde on Salmonella Saintpaul biofilm on a stainless steel surface. J. Gen. Appl. Microbiol. 2014, 60, 119-121. [CrossRef]

102. Karampoula, F.; Giaouris, E.; Deschamps, J.; Doulgeraki, A.I.; Nychas, G.-J.E.; Dubois-Brissonnet, F. Hydrosol of Thymbra capitata is a highly efficient biocide against Salmonella enterica serovar Typhimurium biofilms. Appl. Environ. Microbiol. 2016, 82, 5309-5319. [CrossRef]

103. Liu, Q.; Niu, H.; Zhang, W.; Mu, H.; Sun, C.; Duan, J. Synergy among thymol, eugenol, berberine, cinnamaldehyde and streptomycin against planktonic and biofilm-associated food-borne pathogens. Lett. Appl. Microbiol. 2015, 60, 421-430. [CrossRef]

104. Laird, K.; Armitage, D.; Phillips, C. Reduction of surface contamination and biofilms of Enterococcus sp. and Staphylococcus aureus using a citrus-based vapour. J. Hosp. Infect. 2012, 80, 61-66. [CrossRef] [PubMed]

105. Qayyum, S.; Khan, A.U. Nanoparticles vs. biofilms: A battle against another paradigm of antibiotic resistance. Med. Chem. Commun. 2016, 7, 1479-1498. [CrossRef]

106. Chifiriuc, M.C.; Grumezescu, V.; Grumezescu, A.M.; Saviuc, C.; Lazăr, V.; Andronescu, E. Hybrid magnetite nanoparticles/Rosmarinus officinalis essential oil nanobiosystem with antibiofilm activity. Nanoscale Res. Lett. 2012, 7, 209. [CrossRef] [PubMed]

107. Iannitelli, A.; Grande, R.; Di Stefano, A.; Di Giulio, M.; Sozio, P.; Bessa, L.J.; Laserra, S.; Paolini, C.; Protasi, F.; Cellini, L. Potential antibacterial activity of carvacrol-loaded poly(DL-lactide-co-glycolide) (PLGA) nanoparticles against microbial biofilm. Int. J. Mol. Sci. 2011, 12, 5039-5051. [CrossRef]

108. Bilcu, M.; Grumezescu, A.M.; Oprea, A.E.; Popescu, R.C.; Mogoșanu, G.D.; Hristu, R.; Stanciu, G.A.; Mihailescu, D.F.; Lazar, V.; Bezirtzoglou, E.; et al. Efficiency of vanilla, patchouli and ylang ylang essential oils stabilized by iron oxide@C14 nanostructures against bacterial adherence and biofilms formed by Staphylococcus aureus and Klebsiella pneumoniae clinical strains. Molecules 2014, 19, 17943-17956. [CrossRef]

109. Liakos, I.L.; Grumezescu, A.M.; Holban, A.M.; Florin, I.; D’Autilia, F.; Carzino, R.; Bianchini, P.; Athanassiou, A. Polylacticacidlemongrass essential oil nanocapsules with antimicrobial properties. Pharmaceuticals 2016, 9, 42. [CrossRef]

110. Grumezescu, A.M.; Andronescu, E.; Oprea, A.E.; Holban, A.M.; Socol, G.; Grumezescu, V.; Chifiriuc, M.C.; Iordache, F.; Maniu, H. MAPLE fabricated magnetite@ Melissa officinalis and polylactic acid: Chitosan coated surfaces with anti-staphylococcal properties. J. Sol-Gel Sci. Technol. 2015, 73, 612-619. [CrossRef]

111. Giongo, J.L.; de Almeida Vaucher, R.; Fausto, V.P.; Quatrin, P.M.; Lopes, L.Q.S.; Santos, R.C.V.; Gündel, A.; Gomes, P.; Steppe, M. Anti-Candida activity assessment of Pelargonium graveolens oil free and nanoemulsion in biofilm formation in hospital medical supplies. Microb. Pathog. 2016, 100, 170-178. [CrossRef] [PubMed]

112. Shemesh, R.; Krepker, M.; Natan, M.; Danin-Poleg, Y.; Banin, E.; Kashi, Y.; Nitzan, N.; Vaxman, A.; Segal, E. Novel LDPE/halloysite nanotube films with sustained carvacrol release for broad-spectrum antimicrobial activity. RSC Adv. 2015, 5, 87108-87117. [CrossRef] 